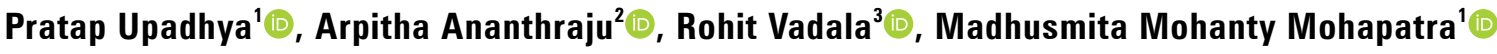

'Department of Pulmonary Medicine, Jawaharlal Institute of Postgraduate Medical Education \& Research, Puducherry, India ${ }^{2}$ Department of Obstetrics and Gynecology, Jawaharlal Institute of Postgraduate Medical Education \& Research, Puducherry, India

${ }^{3}$ Department of Pulmonary Medicine, All India Institute of Medical Sciences, New Delhi, India

\section{Endocrine paraneoplastic syndromes in lung cancer: a respiratory physician's perspective}

\begin{abstract}
Lung malignancy is known to be one of the leading causes of cancer-related mortality. Endocrine paraneoplastic syndromes in lung cancer are common. These are due to secretion of various substances and not because of direct tumour invasion or metastasis. These syndromes have also been associated with lung cancer prognosis. This review describes the many endocrine paraneoplastic syndromes seen in lung cancer and narrates their incidence, biology, clinical features, diagnosis, and management.
\end{abstract}

Key words: endocrine paraneoplastic syndromes, lung cancer, hypercalcaemia, hyponatraemia, small-cell lung carcinoma

Adv Respir Med. 2021; 89: 403-412

\section{Introduction}

Lung cancer is considered to be the foremost cause of cancer-related mortality around the world [1]. Mortality rate in lung cancer is significant and is considered equal to that of prostrate and breast cancers combined. This is mainly because most of these patients present in advanced stages of cancer at the time of diagnosis [2]. The most important risk factor for lung cancer to date is tobacco smoke [3]. The late diagnosis of lung cancer in advanced stages is mainly due to the lack of clinical findings. Some patients may seek medical advice for symptoms not directly related to a malignancy because of the appearance of paraneoplastic syndromes, which in turn may lead to the diagnosis of cancer in the early stage, with early initiation of chemotherapy [4].

Paraneoplastic syndromes (PNS) are seen in malignant conditions with the clinical features caused by either production of hormones or functional peptides secreted by tumour itself. These should not be induced by direct infiltration and growth of the primary malignancy or metastases [5]. Improper immune cross-reaction of tumour cells with normal host cells can also be the rare cause of this syndrome [6]. Most common ma- lignancy associated with PNS is lung cancer. Ten percentage of patients with lung cancer can have these syndromes [7]. In lung cancer, PNS are numerous (Table 1). Humoral hypercalcaemia of malignancy along with the syndrome of inappropriate antidiuretic hormone secretion seen respectively more in squamous-cell carcinoma and small-cell carcinoma are two of the most common endocrine PNS. The size of the primary tumour or stage of cancer has no relation with the symptom severity in these syndromes. These syndromes are diagnosed with specific criteria (Table 2), but all need not be fulfilled in clinical practice [5]. Especially, demonstration of hormones in tumour biopsy tissue is not practical in many cases.

The present review aims to present the incidence, tumour biology, clinical features, diagnos-

Table 1. Lung cancer-associated paraneoplastic endocrine syndromes

Humoral hypercalcaemia of malignancy

Syndrome of inappropriate antidiuretic hormone secretion

Ectopic Cushing's syndrome

Carcinoid syndrome

Rare: Acromegaly, hypoglycaemia, glucagonoma syndrome, Zollinger-Ellison syndrome

Address for correspondence: Pratap Upadhya, Department of Pulmonary Medicine, Jawaharlal Institute of Postgraduate Medical Education \& Research, Puducherry, India; e-mail:drpratapujipmer@gmail.com

DOI: 10.5603/ARM.a2021.0075 | Received: 01.01.2021 | Copyright (C 2021 PTChP | ISSN 2451-4934 | e-ISSN 2543-6031

This article is available in open access under Creative Common Attribution-Non-Commercial-No Derivatives 4.0 International (CC BY-NC-ND 4.0) license, allowing to download articles and share them with others as long as they credit the authors and the publisher, but without permission to change them in any way or use them commercially. 


\section{Table 2. Diagnostic criteria for paraneoplastic endocrine syndromes}

Endocrine function abnormality with absent physiologic feedback regulation

Respective endocrine lung should not have any metastasis

Worsening not explained by increasing tumour burden

Cancer treatment improves endocrine function

Tumour biopsy sample showing evidence of either hormone sub-

stance or its production tic criteria, and treatment options for endocrine paraneoplastic syndromes in lung cancer.They are briefly described in Table 3.

\section{Humoral hypercalcaemia of malignancy (HHM)}

\section{Incidence}

Ten percent of all patients with advanced lung malignancy can have hypercalcaemia, and among

Table 3. Four most common endocrine paraneoplastic syndromes encountered in lung cancer and their features

\begin{tabular}{|c|c|c|c|c|}
\hline & НHМ & SIADH & $\begin{array}{l}\text { Ectopic cushing } \\
\text { syndrome }\end{array}$ & Carcinoid syndrome \\
\hline Incidence & $\begin{array}{l}\text { Baseline: } 2-6 \% \\
\text { During course of cancer: } 10 \% \\
\text { Most common histology: } \\
\text { squamous-cell carcinoma }\end{array}$ & $\begin{array}{l}\text { SCLC } 70 \% \text { of all PNS SIADH } \\
\text { In SCLC } 7-16 \% \\
\text { In NSCLC }<1 \%\end{array}$ & $\begin{array}{l}10 \% \text { of Cushing's syndrome } \\
\text { are paraneoplastic } \\
50-50 \% \text { of PN-lung NET } \\
\text { (SCLC, carcinoid) }\end{array}$ & $\begin{array}{l}1-5 \% \text { in bronchopulmo- } \\
\text { nary NET }\end{array}$ \\
\hline Mechanism & $\begin{array}{l}\text { PTHrP (most common): bind } \\
\text { to PTH receptors in the bone, } \\
\text { kidney and influence calci- } \\
\text { um, phosphorous regulation }\end{array}$ & $\begin{array}{l}\text { Ectopic ADH secretion by cancer } \\
\text { cells which inhibit free-water } \\
\text { excretion in the distal tubule } \\
\text { of the kidney }\end{array}$ & $\begin{array}{l}\text { Cancer cells express POMC } \\
\text { precursor gene which is } \\
\text { translated into a prohormone } \\
\text { later cleaved into ACTH }\end{array}$ & $\begin{array}{l}\text { Serotonin release by } \\
\text { cancer cells. Can be pre- } \\
\text { cipitated by certain food, } \\
\text { exercise, or alcohol }\end{array}$ \\
\hline $\begin{array}{l}\text { Clinical } \\
\text { features }\end{array}$ & $\begin{array}{l}\text { Altered sensorium, polydip- } \\
\text { sia, polyuria, hypertonia, } \\
\text { renal failure, vomiting }\end{array}$ & $\begin{array}{l}\text { 1) Depends on duration } \\
\text { and degree of acuity } \\
\text { 2) Frequent falls, weight gain, } \\
\text { seizures, vomiting, depression } \\
\text { and rarely come }\end{array}$ & $\begin{array}{l}\text { 1) Carcinoid: typical cush- } \\
\text { ingoid features like cen- } \\
\text { tripetal fat distribution, } \\
\text { systemic hypertension, } \\
\text { proximal myopathy } \\
\text { 2) SCLC: less cushingoid } \\
\text { features, hyperglycaemia } \\
\text { common, unexpected } \\
\text { weight gain due to chron- } \\
\text { ic water retention }\end{array}$ & $\begin{array}{l}\text { 1) Acute: prolonged } \\
\text { flushing in upper } \\
\text { torso anteriorly, } \\
\text { bronchospasm, } \\
\text { or diarrhea } \\
\text { 2) Chronic: fibrosis of } \\
\text { right heart valves, ret- } \\
\text { roperitoneum } \\
\text { 3) Rare: carcinoid crisis } \\
\text { causing hypotension, } \\
\text { cardiac arrest }\end{array}$ \\
\hline Diagnosis & $\begin{array}{l}\uparrow \mathrm{Ca} \\
\uparrow \mathrm{PTHrP} \\
\downarrow / \mathrm{N} \mathrm{PTH}\end{array}$ & $\begin{array}{l}\text { Clinically euvolemic: } \\
\text { serum sodium }<125 \mathrm{mEq} / \mathrm{l}, \\
\text { urinary sodium }>40 \mathrm{mmol} / \mathrm{L} \text {, } \\
\text { urine osmolality }>100 \mathrm{m0sm} / \mathrm{kg} \\
\text { Rule out other causes of hypona- } \\
\text { traemia - drug-induced, excess } \\
\text { fluids, low intake due to cachexia }\end{array}$ & $\begin{array}{l}\text { 1) Demonstration of hyper- } \\
\text { cortisolism by- increased } \\
24 \text { UFC or salivary cortisol } \\
\text { 2) } 1 \text { mg dexamethasone } \\
\text { suppression test } \\
\text { 3) High serum ACTH level } \\
\text { with the absence of } \\
\text { a pituitary tumour by CT } \\
\text { or MRI brain }\end{array}$ & $\begin{array}{l}\text { 1) } 24 \text {-hour urine } 5 \text {-HIAA } \\
\text { 2) Radiolabeled oct- } \\
\text { reotide }\end{array}$ \\
\hline Treatment & $\begin{array}{l}\text { 1) Tumour excision } \\
\text { 2) Restore intravascular } \\
\text { volume } \\
\text { 3) Bisphosphonates, calci- } \\
\text { tonin, hemodialysis }\end{array}$ & $\begin{array}{l}\text { 1) Treatment of the underlying } \\
\text { tumour } \\
\text { 2) Firstline - fluid restriction } \\
(<1 \mathrm{~L} \text { day) } \\
\text { 3) Demeclocycline, vaptans }\end{array}$ & $\begin{array}{l}\text { 1) Tumour excision } \\
\text { 2) Ketoconazole, octreotide } \\
\text { 3) Bilateral adrenalectomy } \\
\text { in refractory cases }\end{array}$ & $\begin{array}{l}\text { 1) Surgical excision of } \\
\text { tumour } \\
\text { 2) During carcinoid crisis: } \\
\text { octreotide } \\
\text { 3) Pre lung surgery } \\
\text { manipulation of tu- } \\
\text { mour-octreotide not } \\
\text { usually recommended }\end{array}$ \\
\hline
\end{tabular}

Conversion factors for SI: calcium values to $\mathrm{mmol} / \mathrm{L}$, multiply by 0.25 ; cortisol values to $\mathrm{nmol} / \mathrm{L}$, multiply by 27.588 ; osmolality values to $\mathrm{mmol} / \mathrm{kg}$, multiply by $1 ; \mathrm{PTH}$ values to $\mathrm{ng} / \mathrm{L}$, multiply by 1 ; and sodium values to $\mathrm{mmol} / \mathrm{L}$, multiply by 1 .

ACTH — adrenocorticotropic hormone; CT — computed tomography; HHM — humoral hypercalcaemia of malignancy; HIAA — 5-hydroxyindoleacetic acid; MRI — magnetic resonance imaging; NET — neuroendocrine tumour; POMC — proopiomelanocortin; PTH — parathyroid hormone; PTHrP — PTH-related protein; SIADH — syndrome of inappropriate antidiuretic hormone secretion 
these, the thirty-day mortality rate can be as high as $50 \%[8,9]$. Bone metastases or altered parathyroid gland function are usually absent in these cases. In lung cancer, the incidence of hypercalcaemia is around $5 \%$ at baseline diagnosis and can be twice as this eventually (around 8-12\%) during the disease course [5-7, 10]. Most common histology causing HHM is squamous-cell carcinoma, and in up to one-fourth of them, hypercalcaemia can be the presenting feature $[5,6,10-12]$.

\section{Biology and mechanism}

In lung cancer patients, hypercalcaemia in the majority of the cases is usually caused by HHM [13, 14]. Four mechanisms have been observed in malignancy-related HHM (Table 4). The main and most important mechanism of action is the parathyroid hormone-related protein (PTHrP) secreted from cancer cells [12, 14, 15]. Ectopic parathyroid hormone production is one of the rare mechanisms [13]. Sometimes, post-chemotherapy, chronic G-CSF exposure can cause hypercalcaemia in few of them as it promotes osteoclastic bone resorption [16, 17].

Parathyroid hormone molecule has eightyfour amino acids while the PTHrP molecule has 139 to 173 amino acids. These two substances manifest C-terminal portions differently but have a similar first 13 amino acids N-terminal. PTHrP modifies itself into a configuration and binds to the PTH receptor. It can simultaneously bind to other PTH receptors and utilise different effects from PTH [18]. PTHrP binds to receptors of PTH in the kidney and bone. This subsequently influences the bone resorption and renal control of electrolytes, namely phosphate and calcium. PTHrP does not effect on the vitamin D3 1-alpha hydroxylase action unlike parathyroid hormone. In some animal model studies, in a squamous-cell carcinoma cell line, the amphiregulin-EGFR signalling system reconstitution caused HHM [19].

In patients with tumours originating from the lungs [8], including several other organ NETs, hypercalcaemia secondary to PTH secretion has been described [20].

Rarely, tumour cells can release interleukins that can activate the osteoclasts (like IL-1) which can be the cause of malignancy-related hypercalcaemia [21].

\section{Clinical features and diagnosis}

In lung cancer, HHM incidence is more frequent in those patients with significant disease burden (locally advanced or metastatic disease) [21]. The symptom level depends on the serum calcium concen-
Table 4. Humoral hypercalcaemia of malignancy causes

Parathyroid hormone-related protein

1.25 dihydroxy vitamin $\mathrm{D}$

Parathyroid hormone

Granulocyte colony-stimulating factor

tration (calcium levels more than $14 \mathrm{mg} / \mathrm{dL}$ are considered severe), timing of the onset and the patient's precancer neurologic and renal function [22, 23].

Moderate hypercalcaemia (serum level of 12-14 mg/dL) may result in neuromuscular symptoms (proximal myopathy, fatigue), neuropsychiatric symptoms (anxiety, confusion), circulatory disturbances (polydipsia, severe dehydration causing acute renal failure, polyuria), and gastrointestinal manifestations (abdominal pain, constipation, and rarely pancreatitis),

Hypercalcaemia, when severe, can cause cognitive impairment, confusion, and even coma. Cardiac conduction disturbance and hypotension causing death may also be seen $[5,6,13,22]$.

Many lung cancer patients can be emaciated due to cancer-related cachexia with low serum protein values. So, their serum calcium levels need correction depending on the serum albumin values. Patient's calcium and albumin values estimation should be always made simultaneously [6].

The diagnosis is confirmed by the following laboratory tests: high serum levels of ionized and total calcium, low to normal parathyroid hormone (PTH) level and high PTH-related protein (PTHrP) concentration [8].

\section{Treatment}

Treatment of the underlying malignancy as radically as possible is the most successful therapy strategy [6]. The goal of medical care should be attaining electrolyte equilibrium and restoring intravascular volume to prevent the immediate acute complications of serum hypercalcaemia. Two to three liters of intravenous normal $0.9 \%$ saline solution will achieve this. Fluid substitution decreases calcium reabsorption in the kidney by increasing the glomerular filtration rate [7, 22]. Medications causing hypercalcaemia (like calcium-containing antacids, supplements of calcium, vitamin D, diuretics like thiazides) or that aggravating mental status changes should be stopped whenever possible [9].

In refractory persistent hypercalcaemia, treatment to reduce the elevated calcium levels should be done as per latest guidelines (including bisphosphonates and possibly denosumab) [6, 23]. Serum calcium level starts to decrease within a day 
and normal values of calcium can be seen within a week following administration of intravenous bisphosphonates. Bisphosphonates have an influence on serum calcium levels for up to 3 weeks [5, 24]. In treating HHM, bisphosphonates are proven to be the safest and most effective agents [24]. They also enhance the survival of patients with bone metastasis [23]. The important complications of bisphosphonates are jaw osteonecrosis due to local vessel vasoconstriction and acute renal failure. Jaw osteonecrosis can cause severe pain locally, jaw swelling, tooth loss, and, rarelysoft tissue loss exposing the underlying bone $[5,6]$.

In cases of PTHrP-related hypercalcaemia, cinacalcet can be helpful [25].

A low calcium diet and steroids are usually less effective.

Dialysis is generally reserved for those with severe hypercalcaemia causing life-threatening symptoms or in patients with acute renal failure.

\section{Prognosis}

In lung cancer, those with significant disease burden (locally advanced or metastatic disease) have more chances of having HHM with mean survival of only around 2 months and poor prognosis [26].

In a study of 1,149 histologically proven lung cancer patients, hypercalcaemia was seen in $6 \%$. Among those with hypercalcaemia, squamous-cell carcinoma was found in $51 \%$, adenocarcinoma in $22 \%$ and small-cell carcinoma in $15 \%$. Those with hypercalcaemia mostly had advanced disease (stage 3 or more) with a median survival of only a few months [11].

Serum PTHrP levels in patients with HHM can give information regarding prognosis. In some cases, it can be used to assess tumour response posttreatment. It may also predict the reaction to bisphosphonates. Studies have shown that concentrations above $12 \mathrm{pmol} / \mathrm{L}$ are frequently associated with both a smaller reduction in hypercalcaemia and with recurrence of hypercalcaemia within fourteen days of therapy [27, 28].

Prognosis of lung cancer-associated hypercalcaemia is generally poor. Those who become normocalcaemic after bisphosphonate therapy survive better (53 days vs 19 days ) [27].

\section{Syndrome of inappropriate antidiuretic hormone secretion}

\section{Incidence}

A syndrome of inappropriate antidiuretic hormone secretion (SIADH) causing hypona- traemia with cancer background was noticed in 1957 for the first time. In 1963, from a lung tumour sample (small-cell carcinoma), an agent with ADH-like action was isolated [29, 30]. This syndrome manifests as hyponatraemia with euvolemia clinically, low serum osmolality and unsuitably high urine osmolality. Diagnosis has a specific criterion (Table 4). The tumour cell more commonly produces antidiuretic hormone and rarely atrial natriuretic peptide leading to paraneoplastic hyponatraemia. Antidiuretic hormone increases reabsorption of free water and atrial natriuretic peptide induces natriuresis [31].

SIADH is found in $1-2 \%$ of patients with lung cancer. SIADH causing clinical symptoms has been seen to occur in around $10 \%$ of lung cancer patients, mainly with small-cell carcinoma histology. Less than one percent of paraneoplastic hyponatraemia is caused by NSCLC. In SCLC, tumour stage does not correlate with the incidence of SIADH. Overall, around 70\% of paraneoplastic SIADH cases are caused by SCLC [32-34].

\section{Biology/mechanism}

ADH is a 9-amino acid peptide usually produced by neurohypophysis. The peptide binds to receptors in the kidney to reduce the excretion of free water. When plasma osmolality exceeds $280 \mathrm{mOsm} / \mathrm{kg}$, the pituitary increases $\mathrm{ADH}$ release, causing the kidney to retain more free water and maintain fluid and osmolar balance.

In patients with SCLC, ectopic ADH production causes hyponatraemia by inhibiting free-water excretion in the distal tubule of the kidney. $\mathrm{ADH}$ mRNA is expressed in SCLC cells and the peptide is translated and secreted. Measured levels of $\mathrm{ADH}$ in plasma are often increased in SCLC [35]. A subgroup of hyponatraemia and concurrent SCLC cases have no detectable levels of plasma $\mathrm{ADH}$. The tumours in these patients express ANP mRNA, secrete the peptide, and have high plasma ANP levels [36].

\section{Clinical findings/diagnosis}

In SIADH, the level of sodium in serum and its time of onset determines the symptoms. Initially, the patients can have only headache and fatigue as presenting complaints. However, acute onset ( $<48$ hours) and severe hyponatraemia (serum sodium level of less than $120 \mathrm{meq} / \mathrm{L}$ ) can cause general seizures, altered mental status and rarely death due to cerebral oedema. Usually, chronic hyponatraemia patients are asymptomatic, especially when it's mild to a moderate degree.

In the background of hyponatraemia with clinical euvolemia status, $>40 \mathrm{mmol} / \mathrm{L}$ of sodium 


\section{Table 5. Syndrome of inappropriate antidiuretic hormone secretion diagnosis criteria}

\author{
Serum sodium level of less than $134 \mathrm{mEq} / \mathrm{L}$ \\ Osmolality of plasma less than $275 \mathrm{~m} 0 \mathrm{sm} / \mathrm{kg}$ \\ Osmolality of urine more than $500 \mathrm{~m} 0 \mathrm{sm} / \mathrm{kg}$ \\ Concentration in urine more than $20 \mathrm{mEq} / \mathrm{L}$ \\ All should be absent: hypovolaemia, adrenal insufficiency, \\ and hypothyroidism
}

in urine or $>100 \mathrm{mOsm} / \mathrm{kg}$ of osmolality in urine gives a clue to the diagnosis of SIADH [37]. The diagnosis of SIADH is confirmed by laboratory tests as given in Table 5 .

Always, in patients having hyponatraemia in the setting of lung cancer, other causes of low serum sodium like inadequate sodium intake, drug-induced kidney injury or excess intravenous hypotonic solutions usage should be excluded.

\section{Treatment}

Surgical excision of the tumour is always the ideal treatment and when successful, can bring back the serum sodium level to normal in only some patients [33]. In SCLC, post-chemotherapy symptoms resolution can be seen in up to $80 \%$ of cases, but the syndrome would relapse along with the tumour (in $60-70 \%$ of patients) [33, 34]. In SCLC, rarely can chemotherapy result in tumour lysis syndrome contributing to acute SIADH [38].

As in any SIADH case, in asymptomatic milder hyponatraemia patients, reduced $(1 \mathrm{~L} /$ day) intake of free water is the first step. In symptomatic hyponatraemia with serum sodium < $120 \mathrm{mEq}$, intravenous administration of $3 \%$ sodium chloride solution with an infusion speed of up to $1 \mathrm{~mL} / \mathrm{kg} / \mathrm{hour}$ is necessary for the first few hours at least. Correction of serum sodium level should be gradual as acute restoration can lead to irreversible demyelination.

Pharmacologic treatments can be used when conservative measures fail. Demeclocycline lowers renal response to ADH. Vasopressin receptor antagonists like conivaptan and tolvaptan enhance urine excretion of free water. These are effective in some cases.

\section{Prognosis}

SIADH per se carries an independent poor prognosis in malignancy [39].

In one study, SCLC patients with persistent hyponatraemia due to SIADH had worse survival. In this study, 61 patients had sodium level of less than $130 \mathrm{mEq} / \mathrm{L}$ and received at least two cycles of chemotherapy. Among these 61 subjects, com- pared to 46 patients whose sodium normalised (to $136 \mathrm{mEq} / \mathrm{L})$, the 15 patients in whom there was persistent hyponatraemia $(<136 \mathrm{mEq} / \mathrm{L})$ post-chemotherapy had worse survival [40].

\section{Ectopic Cushing's syndrome (ECS)}

\section{Incidence}

In 1962, for the first time, connection between CS and ectopic production of adrenocorticotrophic hormone (ACTH) was established in a patient with severe hyperadrenocorticism who was found to have SCLC [41]. In Cushing's syndrome, in up to $10 \%$ of cases, the cause can be paraneoplastic [44]. In most of these cases, malignancy involved is lung NET (small-cell carcinoma or bronchial carcinoids) [41-44]. In non-neuroendocrine tumours, rarely are ECS reported [45].

\section{Biology and mechanism}

Ectopic production of ACTH happens to be the foremost cause of this endocrine syndrome in lung cancer patients [46]. Rarely, it is caused by corticotropin-releasing hormone (CRH) secretion from tumour cells [47].

The precursor gene, proopiomelanocortin (POMC), is expressed more in the cancer cells from which a 241-amino acid prohormone is translated and then cleaved into ACTH (39 amino acids), melanocyte-stimulating hormone, and opiate-like hormones. The ACTH binds to receptors in the adrenal gland, causing them to produce excessive glucocorticoid and mineralocorticoid hormones [48]. CRH is a 41-amino acid peptide produced and released in the hypothalamus paraventricular nuclei that stimulates the release of ACTH from the pituitary.

\section{Clinical features and diagnosis}

Systemic manifestations in this syndrome are mainly due to increased serum cortisol levels. The common clinical features of ECS are skin purple striae, moon like face, acne, proximal myopathy, oedema of the periphery, systemic hypertension, primary metabolic alkalosis, and persistent serum hypokalaemia. Weight gain (due to chronic water retention or centripetal fat distribution) may be one of the rare features in those with lung cancer-related ECS unlike in those without ECS where weight loss is seen because of cachexia [7]. Most of them also have hyperglycaemia [48, 49]. In ECS, due to SCLC, classical signs of Cushing's syndrome are rare. An important reason for this finding could be the aggressive nature of SCLC causing only brief exposure to excessive ACTH $[5,50]$. 
Those having SCLC with ECS getting chemotherapy are at increased risk for opportunistic infections [51]. ECS is also a risk factor for VTE (2\%) [52]. This risk further may increase after surgery of the tumour (4\%) [53].

Diagnostic laboratory findings include the following [54]:

1. Minimum of 2 increased measurements of 24-h urine free cortisol;

2. Salivary cortisol sample $>145 \mathrm{ng} / \mathrm{dL}$ between 23:00-24:00;

3. $1 \mathrm{mg}$ of dexamethasone suppression test.

An ACTH level can differentiate ECS from Cushing's in cases of proven serum or urine hypercortisolism. ECS suspicion is raised when an elevated morning ACTH is seen along with the absent pituitary tumour in brain CT or MRI. Highdose dexamethasone will not suppress an ectopic source (like in lung cancer) of ACTH. Bronchial carcinoids are an exception, because in some cases with this tumour type, serum ACTH and cortisol levels have been suppressed by high-dose dexamethasone [55].

To locate the primary tumour in the lungs, whole body somatostatin receptor scintigraphy or thorax imaging like CT can be used.

\section{Treatment}

Radical excision of the tumour is the best treatment [56]. When radical therapy of the tumour is unattainable, medications directed to cease the secretion of cortisol (ketoconazole, metyrapone and other drugs) or block (octreotide may block the release of ACTH) are required [7, 57]. With careful monitoring of serum potassium, antihypertensive agents and diuretics can also be used to control symptoms.

Bilateral adrenalectomy is the option used as a last resort in case of no response to medications [5].

\section{Prognosis}

Prognosis is affected by tumour type and degree of cortisol level as both these factors influence mortality and morbidity [56].

Most of the patients with SCLC and ECS present at an advanced stage. Even with chemotherapy, their mortality is significantly high since many of these tumours are chemoresistant $[5,7,56]$.

\section{Carcinoid syndrome}

\section{Incidence}

Neuroendocrine tumours of the bronchopulmonary system account for around $20 \%$ of all lung malignancies and include typical carcinoid, atypical carcinoid, large-call carcinoma and SCLC [58].

In neuroendocrine lung cancer, the release of serotonin by tumour cells might trigger the syndrome only in $1-5 \%$ of the cases [59]. A lower rate of carcinoid syndrome is seen in lung NET as they produce less serotonin than midgut NET [58]. In patients having localised disease (like in most of the cases of lung NET), carcinoid syndrome is seen most often with tumours of bigger size $(>5 \mathrm{~cm})$ and those with concurrent liver metastasis [60].

\section{Biology and mechanism}

Carcinoid syndrome results from the release of vasoactive substances such as serotonin into the systemic circulation. As many as 40 substances (dopamine and many others) related to carcinoid syndrome have been identified as being the potential causes. The release of these substances can be triggered by increased adrenergic activities, such as physical exercise, or increased intake of foods rich in amines (chocolate, kiwi, avocado banana, and nuts) or alcohol.

\section{Clinical features and diagnosis}

Some may have acute symptoms like cutaneous flushing, secretory diarrhoea, and bronchospasm. The long-term results of persistently elevated hormone levels include telangiectasias of veins, valvular heart disease (right side more commonly involved), and retroperitoneum fibrosis. Flushing of the skin can be prolonged in the setting of carcinoid syndrome due to lung NET and it occurs more in the upper anterior part of the body [61, 62].

Carcinoid syndrome-associated bronchospasm is less typical and these patients usually have concurrent flushing, sneezing and dyspnoea [63]. In a retrospective study of 748 carcinoid syndrome patients, bronchospasm was seen in $15 \%$ [63].

In few cases, due to excessive production of serotonin and its release into the systemic circulation, an acute form of the syndrome can be seen. This is known as carcinoid crisis. These patients can have tachycardia, hypotension, bronchospasm, and even rarely sudden death. Carcinoid crisis is more common after stressful procedures such as anaesthesia, surgery or even radiologic interventions [64]. It can also happen spontaneously.

The evaluation of carcinoid syndrome is with a 24-hour urine collection for the most crucial metabolite of serotonin, 5-Hydroxyindoleacetic 
acid (5-HIAA). This test has a specificity of approximately $90 \%$ [65].

Radiolabelled octreotide can be used to detect lung neuroendocrine tumours with ectopic hormone production as almost $80 \%$ of them demonstrate somatostatin receptors [66].

\section{Treatment}

Excision of the tumour is the best treatment [67]. Unlike other organ NETs (even with significant liver metastasis), carcinoid crisis risk with lung NETs is low, and hence prophylactic administration of octreotide before any tumour manipulation (biopsy or resection) is not recommended [62]. But still, when handling such tumours, clinicians should be aware of the possibility of the carcinoid crisis and the benefit of octreotide in such a scenario.

\section{Rare syndromes}

\section{Hypoglycaemia}

Lung cancer-associated paraneoplastic hypoglycaemia is rare. Non-isletcell tumours with insulin secretion and tumours releasing substances which can cause hypoglycaemia by non-insulin based mechanism are the main causes [68]. This condition is labelled as non-islet cell tumour hypoglycaemia (NICTH). Pulmonary tumours causing this condition are malignant mesothelioma, solitary fibrous tumour and adenocarcinomas [6].

In most of the cases, hypoglycaemia is caused by excess insulin release due to the secretion of peptides like precursors of insulin-like growth factor 2 (IGF-2), insulin-like growth factor 1, and sometimes glucagon-like peptide-1 which are capable of causing glucose utilisation by different mechanisms [68]. Rarely high tumour load having excess glucose utilisation, significant liver infiltration by tumour per se, or tumour metastasis to the endocrine gland (pituitary or adrenal) causing their destruction is the cause of hypoglycaemia in these patients [68].

NICTH is clinically characterised by recurrent hypoglycaemic episodes which affect elderly patients more often. In some, these hypoglycaemic episodes may direct towards the underlying undiagnosed cancer [69, 70].

Diagnosis depends on tumour type the patient is having. In NICTH acute phase, we can find decreased values of following substances in serum-insulin (normal range: 1.44-3.6 $\mu \mathrm{IU} /$ $\mathrm{mL}$ ) and C-peptide (normal range: $0.3 \mathrm{ng} / \mathrm{mL}$ ). They would also have increased levels of the following substances in serum: growth hormone, insulin-like growth factor 1, insulin-like growth factor 2 and IGF2:IGF1 ratio. In insulinoma acute phase, we can find increased value of both insulin and C-peptide levels in serum [6, 70].

Surgery of the tumour is the best management option in these patients. The essential goal in case of any hypoglycaemic emergencies is to bring back blood glucose to near expected values with $25 \%$ or $50 \%$ solution of dextrose. Oral glucose will help in few cases. In the long run, treatment of hypoglycaemia due to this syndrome may require glucagon, growth hormone and corticosteroids [6, 69-71].

\section{Acromegaly}

Only $1 \%$ of acromegaly is caused by growth hormone releasing hormone or growth hormone ectopic secretion by tumour cells. Of these, the majority are caused by carcinoid tumours of the lung and intestine [72]. In most cases, the GHRH gene is expressed by the lung cancer cells, and a 40-44 amino acid peptide is produced. Circulating GHRH peptide binds to receptors in the pituitary gland resulting in the production of excessive amounts of GH 73]. Rarely, lung carcinoid tumours express immunoreactive GHRH and result in abnormal GH secretion [74].

The earliest features of GH excess are hypertrophy of the extremities and face. The diagnosis of ectopic acromegaly is established by elevated serum levels of GHRH or GH, the absence of a pituitary tumour, complete recovery following lung tumour resection, positive GHRH immunostaining, detection of GHRH mRNA, positive bioassay (pituitary cells of rat on culture produce GH when subjected to tumour extract), or GHRH extraction from the tumour tissue [75]. However, coincidental pituitary tumours and lung solid tumours have also been described.

Management of ectopic acromegaly should be surgical resection of the tumour and is often curative in those with lung carcinoid. In those with unresectable or metastatic cancers, medical therapy with somatostatin analogues, such as octreotide and bromocriptine, have been shown to be effective [76].

\section{Ectopic secretion of chorionic gonadotropin}

This syndrome has been reported in large-cell lung carcinoma (LCLC). The syndrome causes Leydig cell hyperplasia which results in raised oestrogen levels and reduced testosterone production. This gives rise to atrophy of testicles with repression of spermatogenesis, and gynecomastia [77]. 


\section{Conclusion}

Despite the availability of new diagnostic techniques and biological and surgical treatment development, lung malignancy mortality is the foremost cause of cancer-related deaths since 1985.

In lung cancer, the small-cell histology type is commonly associated with endocrine paraneoplastic syndromes. These syndromes are easy to diagnose and treat because they have a clear pathogenic pathway. Endocrine paraneoplastic syndromes have both a prognostic role as well as a predictive function in tumour treatment success. The prognosis also depends on the cure of the underlying tumour. Tumour progression can present along with syndrome recurrence. The most common syndrome is humoral hypercalcaemia of malignancy seen in squamous-cell histology and measurement of PTHrP can delineate it from primary hyperthyroidism.

\section{Conflict of interest}

None declared.

\section{References:}

1. Gaga M, Powell CA, Schraufnagel DE, et al. ATS/ERS Task Force on the Role of the Pulmonologist in the Management of Lung Cancer. An official American Thoracic Society/European Respiratory Society statement: the role of the pulmonologist in the diagnosis and management of lung cancer. Am J Respir Crit Care Med. 2013; 188(4): 503-507, doi: 10.1164/rCcm.201307-1269ST, indexed in Pubmed: 23947517.

2. Beckles MA, Spiro SG, Colice GL, et al. Initial evaluation of the patient with lung cancer: symptoms, signs, laboratory tests, and paraneoplastic syndromes. Chest. 2003; 123 (1 Suppl): 97S-104S, doi: 10.1378/chest.123.1 suppl.97s, indexed in Pubmed: 12527569.

3. Dela Cruz CS, Tanoue LT, Matthay RA. Lung cancer: epidemiology, etiology, and prevention. Clin Chest Med. 2011; 32(4): 605-644, doi: 10.1016/j.ccm.2011.09.001, indexed in Pubmed: 22054876.

4. Früh M, De Ruysscher D, Popat S, et al. ESMO Guidelines Working Group. Small-cell lung cancer (SCLC): ESMO Clinical Practice Guidelines for diagnosis, treatment and follow-up. Ann Oncol. 2013; 24 Suppl 6: vi99-v105, doi: 10.1093/annonc/ mdt178, indexed in Pubmed: 23813929.

5. Li Xu, Bie Z, Zhang Z, et al. Clinical analysis of 64 patients with lung-cancer-associated hypercalcemia. J Cancer Res Ther. 2015; 11 Suppl: C275-C279, doi: 10.4103/0973-1482.170539, indexed in Pubmed: 26612452.

6. Reisch N, Reincke M. [Endocrine paraneoplastic syndromes] Internist (Berl). 2018; 59(2): 125-133, doi: 10.1007/s00108017-0377-y, indexed in Pubmed: 29387897.

7. Detterbeck FC, Lewis SZ, Diekemper R, et al. Executive summary: diagnosis and management of lung cancer, 3rd ed: American College of Chest Physicians evidence-based clinical practice guidelines. Chest. 2013; $143(5$ Suppl): 7S-37S, doi: 10.1378/chest.12-2377, indexed in Pubmed: 23649434.

8. Ramos RE, Perez Mak M, Alves MF, et al. Malignancy-related hypercalcemia in advanced solid tumors: survival outcomes. J Glob Oncol. 2017; 3(6): 728-733, doi: 10.1200/ JGO.2016.006890, indexed in Pubmed: 29244985.

9. Mirrakhimov AE. Hypercalcemia of malignancy: an update on pathogenesis and management. N Am J Med Sci. 2015; 7(11): 483-493, doi: 10.4103/1947-2714.170600, indexed in Pubmed: 26713296.

10. Bender RA, Hansen H. Hypercalcemia in bronchogenic carcinoma. A prospective study of 200 patients. Ann Intern Med 1974; 80(2): 205-208, doi: 10.7326/0003-4819-80-2-205, indexed in Pubmed: 4359740.

11. Hiraki A, Ueoka H, Takata I, et al. Hypercalcemia-leukocytosis syndrome associated with lung cancer. Lung Cancer. 2004; 43(3): 301-307, doi: 10.1016/j.lungcan.2003.09.006, indexed in Pubmed: 15165088.

12. Nielsen PK, Rasmussen AK, Feldt-Rasmussen U, et al. Ectopic production of intact parathyroid hormone by a squamous cell lung carcinoma in vivo and in vitro. J Clin Endocrinol Metab. 1996; 81(10): 3793-3796, doi: 10.1210/jcem.81.10.8855839, indexed in Pubmed: 8855839.

13. Goldner W. Cancer-related hypercalcemia. J Oncol Pract. 2016; 12(5): 426-432, doi: 10.1200/jop.2016.011155, indexed in Pubmed: 27170690.

14. Kasper DL, Fauci AS, Hauser SL. Harrison's principles of internal medicine. Mc Graw Hill Education, New York 2015.

15. Yoshimoto K, Yamasaki R, Sakai H, et al. Ectopic production of parathyroid hormone by small cell lung cancer in a patient with hypercalcemia. J Clin Endocrinol Metab. 1989; 68(5): 976-981, doi: 10.1210/jcem-68-5-976, indexed in Pubmed: 2541161.

16. Hiraki A, Ueoka H, Bessho A, et al. Parathyroid hormone-related protein measured at the time of first visit is an indicator of bone metastases and survival in lung carcinoma patients with hypercalcemia. Cancer. 2002; 95(8): 1706-1713, doi: 10.1002/ cncr.10828, indexed in Pubmed: 12365018.

17. Ma Xt, Yu Lw, Fu J. Paraneoplastic syndromes of hypercalcemia and leukocytosis associated with colonic metastases from squamous cell carcinoma of the lung. Int J Colorectal Dis. 2008; 23(1): 129-130, doi: 10.1007/s00384-006-0256-9, indexed in Pubmed: 17211655.

18. Van den Eynden GG, Neyret A, Fumey G, et al. PTHrP, calcitonin and calcitriol in a case of severe, protracted and refractory hypercalcemia due to a pancreatic neuroendocrine tumor. Bone. 2007; 40(4): 1166-1171, doi: 10.1016/j. bone.2006.11.009, indexed in Pubmed: 17188588.

19. Gilmore JL, Gonterman RM, Menon K, et al. Reconstitution of amphiregulin-epidermal growth factor receptor signaling in lung squamous cell carcinomas activates PTHrP gene expression and contributes to cancer-mediated diseases of the bone. Mol Cancer Res. 2009; 7(10): 1714-1728, doi: 10.1158/15417786.MCR-09-0131, indexed in Pubmed: 19825997.

20. Kandil E, Noureldine S, Khalek M, et al. Ectopic secretion of parathyroid hormone in a neuroendocrine tumor: a case report and review of the literature. Int J Clin Exp Med. 2011; 4(3) 234-240, indexed in Pubmed: 21977238.

21. Strewler GJ. The physiology of parathyroid hormone-related protein. N Engl J Med. 2000; 342(3): 177-185, doi: 10.1056/ NEJM200001203420306, indexed in Pubmed: 10639544.

22. McClelland MT. Paraneoplastic syndromes related to lung cancer. Clin J Oncol Nurs. 2010; 14(3): 357-364, doi: 10.1188/10. CJON.357-364, indexed in Pubmed: 20529797.

23. Ricciardi S, de Marinis F. Treatment of bone metastases in lung cancer: the actual role of zoledronic acid. Rev Recent Clin Trials. 2009; 4(3): 205-211, doi: 10.2174/157488709789957718, indexed in Pubmed: 20028333.

24. Stewart AF. Clinical practice. Hypercalcemia associated with cancer. N Engl J Med. 2005; 352(4): 373-379, doi: 10.1056/ NEJMcp042806, indexed in Pubmed: 15673803.

25. Takeuchi Y, Takahashi S, Miura D, et al. Cinacalcet hydrochloride relieves hypercalcemia in Japanese patients with parathyroid cancer and intractable primary hyperparathyroidism. J Bone Miner Metab. 2017; 35(6): 616-622, doi: 10.1007/s00774016-0797-0, indexed in Pubmed: 27873072.

26. Sternlicht H, Glezerman IG. Hypercalcemia of malignancy and new treatment options. Ther Clin Risk Manag. 2015; 11: 1779-1788, doi: 10.2147/TCRM.S83681, indexed in Pubmed: 26675713.

27. Ling PJ, A'Hern RP, Hardy JR. Analysis of survival following treatment of tumour-induced hypercalcaemia with intrave- 
nous pamidronate (APD). Br J Cancer. 1995; 72(1): 206-209, doi: 10.1038/bjc.1995.304, indexed in Pubmed: 7599053.

28. Gurney H, Grill V, Martin TJ. Parathyroid hormone-related protein and response to pamidronate in tumour-induced hypercalcaemia. Lancet. 1993; 341(8861): 1611-1613, doi: 10.1016/0140-6736(93)90756-7, indexed in Pubmed: 8099988.

29. Schwartz WB, Bennett W, Curelop S, et al. syndrome of renal sodium loss and hyponatremia probably resulting from inappropriate secretion of antidiuretic hormone. Am J Med. 1957; 23(4): 529-542, doi: 10.1016/0002-9343(57)90224-3, indexed in Pubmed: 13469824.

30. Amatruda TT, Mulrow PJ, Gallagher JC, et al. Carcinoma of the lung with inappropriate antidiuresis. Demonstration of antidiuretic-hormone-like activity in tumor extract. N Engl J Med. 1963; 269: 544-549, doi: 10.1056/NEJM196309122691102, indexed in Pubmed: 14043255.

31. Raftopoulos H. Diagnosis and management of hyponatremia in cancer patients. Support Care Cancer. 2007; 15(12): 13411347, doi: 10.1007/s00520-007-0309-9, indexed in Pubmed: 17701059.

32. Grohé C, Berardi R, Burst V. Hyponatraemia - SIADH in lung cancer diagnostic and treatment algorithms. Crit Rev Oncol Hematol. 2015; 96(1): 1-8, doi: 10.1016/j.critrevonc.2015.04.005, indexed in Pubmed: 26070626.

33. Iyer P, Ibrahim M, Siddiqui W, et al. Syndrome of inappropriate secretion of anti-diuretic hormone (SIADH) as an initial presenting sign of non small cell lung cancer-case report and literature review. Respir Med Case Rep. 2017; 22: 164-167, doi: 10.1016/j.rmcr.2017.08.004, indexed in Pubmed: 2885608.

34. Fiordoliva I, Meletani T, Baleani MG, et al. Managing hyponatremia in lung cancer: latest evidence and clinical implications. Ther Adv Med Oncol. 2017; 9(11): 711-719, doi: 10.1177/1758834017736210, indexed in Pubmed: 29344107.

35. Anderson RJ, Chung HM, Kluge R, et al. Hyponatremia: a prospective analysis of its epidemiology and the pathogenetic role of vasopressin. Ann Intern Med. 1985; 102(2): 164-168, doi: 10.7326/0003-4819-102-2-164, indexed in Pubmed: 3966753.

36. Johnson BE, Chute JP, Rushin J, et al. A prospective study of patients with lung cancer and hyponatremia of malignancy. Am J Respir Crit Care Med. 1997; 156(5): 1669-1678, doi: 10.1164/ajrccm.156.5.96-10075, indexed in Pubmed: 9372692.

37. Lee CR, Watkins ML, Patterson JH, et al. Vasopressin: a new target for the treatment of heart failure. Am Heart J. 2003; 146(1): 9-18, doi: 10.1016/S0002-8703(02)94708-3, indexed in Pubmed: 12851603.

38. Verzicco I, Regolisti G, Quaini F, et al. Electrolyte disorders induced by antineoplastic drugs. Front Oncol. 2020; 10: 779, doi: 10.3389/fonc.2020.00779, indexed in Pubmed: 32509580.

39. Hermes A, Waschki B, Reck M. Hyponatremia as prognostic factor in small cell lung cancer--a retrospective single institution analysis. Respir Med. 2012; 106(6): 900-904, doi: 10.1016/j.rmed.2012.02.010, indexed in Pubmed: 22405607.

40. Hansen O, Sørensen P, Hansen KH. The occurrence of hyponatremia in SCLC and the influence on prognosis: a retrospective study of 453 patients treated in a single institution in a 10-year period. Lung Cancer. 2010; 68(1): 111-114, doi: 10.1016/j.lungcan.2009.05.015, indexed in Pubmed: 19535164.

41. Meador CK, Liddle GW, Island DP, et al. Cause of Cushing's syndrome in patients with tumors arising from „nonendocrine" tissue. J Clin Endocrinol Metab. 1962; 22: 693-703, doi: 10.1210/jcem-22-7-693, indexed in Pubmed: 14471915.

42. Boddaert G, Grand B, Le Pimpec-Barthes F, et al. Bronchial carcinoid tumors causing Cushing's syndrome: more aggressive behavior and the need for early diagnosis. Ann Thorac Surg. 2012; 94(6): 1823-1829, doi: 10.1016/j.athoracsur.2012.07.022, indexed in Pubmed: 22981254.

43. Kenchaiah M, Hyer S. Cushing's syndrome due to ectopic ACTH from bronchial carcinoid: a case report and review. Case Rep Endocrinol. 2012; 2012: 215038, doi: 10.1155/2012/215038, indexed in Pubmed: 22934197.

44. Young J, Haissaguerre M, Viera-Pinto O, et al. Management of endocrine disease: Cushing's syndrome due to ectopic ACTH secretion: an expert operational opinion. Eur J Endocrinol. 2020; 182(4): R29-R58, doi: 10.1530/EJE-19-0877, indexed in Pubmed: 31999619.
45. Sarid N, Osher E, Gat A, et al. Cushing's syndrome as a harbinger of relapsed nonsmall cell lung cancer. Isr Med Assoc J. 2012; 14(8): 523-524, indexed in Pubmed: 22977976.

46. Yarbro $\mathrm{CH}$, Wujcik D, Gobel BH. Cancer nursing: principles and practice. Jones \& Bartlett Publishers, Burlington 2010.

47. Shahani S, Nudelman RJ, Nalini R, et al. Ectopic corticotropin-releasing hormone (CRH) syndrome from metastatic small cell carcinoma: a case report and review of the literature. Diagn Pathol. 2010; 5: 56, doi: 10.1186/1746-1596-5-56, indexed in Pubmed: 20807418.

48. Delisle L, Boyer MJ, Warr D, et al. Ectopic corticotropin syndrome and small-cell carcinoma of the lung. Clinical features, outcome, and complications. Arch Intern Med. 1993; 153(6): 746-752, indexed in Pubmed: 8383484.

49. Shepherd FA, Laskey J, Evans WK, et al. Cushing's syndrome associated with ectopic corticotropin production and smallcell lung cancer. J Clin Oncol. 1992; 10(1): 21-27, doi: 10.1200/ JCO.1992.10.1.21, indexed in Pubmed: 1309381.

50. Imura $\mathrm{H}$, Matsukura $\mathrm{S}$, Yamamoto $\mathrm{H}$, et al. Studies on ectopic ACTH-producing tumors. II. Clinical and biochemical features of 30 cases. Cancer. 1975; 35(5): 1430-1437, doi: $\quad 10.1002 / 1097-0142(197505) 35: 5<1430:: a i d-c n-$ cr2820350529>3.0.co;2-o, indexed in Pubmed: 164276.

51. Sarlis NJ, Chanock SJ, Nieman LK. Cortisolemic indices predict severe infections in Cushing syndrome due to ectopic production of adrenocorticotropin. J Clin Endocrinol Metab. 2000; 85(1): 42-47, doi: 10.1210/jcem.85.1.6294, indexed in Pubmed: 10634361.

52. Small M, Lowe GD, Forbes CD, et al. Thromboembolic complications in Cushing's syndrome. Clin Endocrinol (Oxf). 1983; 19(4): 503-511, doi: 10.1111/j.1365-2265.1983.tb00025.x, indexed in Pubmed: 6627701.

53. Van Zaane B, Nur E, Squizzato A, et al. Hypercoagulable state in Cushing's syndrome: a systematic review. J Clin Endocrinol Metab. 2009; 94(8): 2743-2750, doi: 10.1210/jc.2009-0290, indexed in Pubmed: 19454584.

54. Guignat L, Bertherat J. The diagnosis of Cushing's syndrome: an Endocrine Society Clinical Practice Guideline: commentary from a European perspective. Eur J Endocrinol. 2010; 163(1): 9-13, doi: 10.1530/EJE-09-0627, indexed in Pubmed: 20375177.

55. Limper AH, Carpenter PC, Scheithauer B, et al. The Cushing syndrome induced by bronchial carcinoid tumors. Ann Intern Med. 1992; 117(3): 209-214, doi: 10.7326/0003-4819-117-3209, indexed in Pubmed: 1319693.

56. Nagy-Mignotte H, Shestaeva O, Vignoud L, et al. Multidisciplinary Thoracic Oncology Group at Grenoble University Hospital, France. Prognostic impact of paraneoplastic cushing's syndrome in small-cell lung cancer. J Thorac Oncol. 2014 9(4): 497-505, doi: 10.1097/JTO.0000000000000116, indexed in Pubmed: 24736072.

57. Nieman LK. Recent updates on the diagnosis and management of Cushing's syndrome. Endocrinol Metab (Seoul). 2018; 33(2): 139-146, doi: 10.3803/EnM.2018.33.2.139, indexed in Pubmed: 29947171.

58. Torniai M, Scortichini L, Tronconi F, et al. Systemic treatment for lung carcinoids: from bench to bedside. Clin Transl Med. 2019; 8(1): 22, doi: 10.1186/s40169-019-0238-5, indexed in Pubmed: 31273555.

59. Hendifar AE, Marchevsky AM, Tuli R. Neuroendocrine tumors of the lung: current challenges and advances in the diagnosis and management of well-differentiated disease. J Thorac Oncol. 2017; 12(3): 425-436, doi: 10.1016/j.jtho.2016.11.2222, indexed in Pubmed: 27890494.

60. Fischer S, Kruger M, McRae K, et al. Giant bronchial carcinoid tumors: a multidisciplinary approach. Ann Thorac Surg. 2001; 71(1): 386-393, doi: 10.1016/s0003-4975(00)02251-7, indexed in Pubmed: 11216797.

61. İkizoğlu G. Red face revisited: flushing. Clin Dermatol. 2014; 32(6): 800-808, doi: 10.1016/j.clindermatol.2014.02.019, indexed in Pubmed: 25441473.

62. Cogen JD, Swanson J, Ong T. Endobronchial carcinoid and concurrent carcinoid syndrome in an adolescent female. Case Rep Pediatr. 2016; 2016: 2074970, doi: 10.1155/2016/2074970, indexed in Pubmed: 27895950. 
63. Soga J, Yakuwa Y, Osaka M. Carcinoid syndrome: a statistical evaluation of 748 reported cases. J Exp Clin Cancer Res. 1999; 18(2): 133-141, indexed in Pubmed: 10464698.

64. Rubin de Celis Ferrari AC, Glasberg J, Riechelmann RP. Carcinoid syndrome: update on the pathophysiology and treatment. Clinics (Sao Paulo). 2018; 73(Suppl 1): e490s, doi: 10.6061 clinics/2018/e490s, indexed in Pubmed: 30133565.

65. Tormey WP, FitzGerald RJ. The clinical and laboratory correlates of an increased urinary 5-hydroxyindoleacetic acid. Postgrad Med J. 1995; 71(839): 542-545, doi: 10.1136/ pgmj.71.839.542, indexed in Pubmed: 7479466.

66. Yeung SCJ, Habra MA, Thosani SN. Lung cancer-induced paraneoplastic syndromes. Curr Opin Pulm Med. 2011; 17(4): 260-268, doi: 10.1097/MCP.0b013e328347bdba, indexed in Pubmed: 21577115.

67. Ahmadieh H, Arabi A. Endocrine paraneoplastic syndromes: a review. Endocrinol Metab Int J. 2015; 1(1): 15-25, doi: 10.15406/emij.2015.01.00004.

68. Iglesias P, Díez JJ. Management of endocrine disease: a clinical update on tumor-induced hypoglycemia. Eur J Endocrinol 2014; 170(4): R147-R157, doi: 10.1530/EJE-13-1012, indexed in Pubmed: 24459236.

69. Kim SW, Lee SE, Oh YL, et al. Nonislet cell tumor hypoglycemia in a patient with adrenal cortical carcinoma. Case Rep Endocrinol. 2016; 2016: 5731417, doi: 10.1155/2016/5731417, indexed in Pubmed: 27957352.

70. Kanaji N, Watanabe N, Kita N, et al. Paraneoplastic syndromes associated with lung cancer. World J Clin Oncol. 2014; 5(3): 197223, doi: 10.5306/wjco.v5.i3.197, indexed in Pubmed: 25114839.

71. Nauck MA, Reinecke M, Perren A, et al. Hypoglycemia due to paraneoplastic secretion of insulin-like growth factor-I in a patient with metastasizing large-cell carcinoma of the lung. Clin Endocrinol Metab. 2007; 92(5): 1600-1605, doi: 10.1210/ jc.2006-2573, indexed in Pubmed: 17299065.

72. Faglia G, Arosio M, Bazzoni N. Ectopic acromegaly. Endocrinol Metab Clin North Am. 1992; 21(3): 575-595, indexed in Pubmed: 1521513.

73. Doga M, Bonadonna S, Burattin A, et al. Ectopic secretion of growth hormone-releasing hormone (GHRH) in neuroendocrine tumors: relevant clinical aspects. Ann Oncol. 2001; 12 Suppl 2: S89-S94, doi: 10.1093/annonc/12.suppl_2.s89, indexed in Pubmed: 11762359.

74. Oberg K, Norheim I, Wide L. Serum growth hormone in patients with carcinoid tumours; basal levels and response to glucose and thyrotrophin releasing hormone. Acta Endocrinol (Copenh). 1985; 109(1): 13-18, doi: 10.1530/acta.0.1090013, indexed in Pubmed: 3923754.

75. Ghazi AA, Amirbaigloo A, Dezfooli AA, et al. Ectopic acromegaly due to growth hormone releasing hormone. Endocrine. 2013; 43(2): 293-302, doi: 10.1007/s12020-012-9790-0, indexed in Pubmed: 22983831.

76. Butler PW, Cochran CS, Merino MJ, et al. Ectopic growth hormone-releasing hormone secretion by a bronchial carcinoid tumor: clinical experience following tumor resection and long-acting octreotide therapy. Pituitary. 2012; 15(2) 260-265, doi: 10.1007/s11102-010-0226-7, indexed in Pubmed: 20379782

77. Metz SA, Weintraub B, Rosen SW, et al. Ectopic secretion of chorionic gonadotropin by a lung carcinoma. Pituitary gonadotropin and subunit secretion and prolonged chemotherapeutic remission. Am J Med. 1978; 65(2): 325-333, doi: 10.1016/0002 9343(78)90827-6, indexed in Pubmed: 210665. 